Louisiana State University

LSU Digital Commons

Faculty Publications

Department of Oceanography \& Coastal

Sciences

8-2002

Element Ratios and Aquatic Food Webs

R. Eugene Turner

Follow this and additional works at: https://digitalcommons.Isu.edu/oceanography_coastal_pubs 


\title{
Element Ratios and Aquatic Food Webs
}

\author{
R. E. TuRNER* \\ Coastal Ecology Institute, Louisiana State University, Baton Rouge, Louisiana 70803
}

\begin{abstract}
Organic matter is the result of concentrating a few non-metals that are relatively rare in the earth's crust. Most of these essential elements are in a rough proportionality within phylogenetic groupings. Life is thus working against a concentration gradient to extract or accumulate these elements, and this metabolic work is accomplished in interrelated and often subtle ways for many other elements. The physiological requirement to sustain these elemental ratios (commonly discussed in terms of the N:P ratios, but also $\mathrm{C}: \mathrm{N}, \mathrm{C}: \mathrm{P}$, and $\mathrm{Si:N}$ ratios) constrains organization at the cellular, organism, and community level. Humans, as geochemical engineers, significantly influence the spatial and temporal distribution of elements and, consequently, their ratios. Examples of these influences include the changing dissolved Si : nitrate and the dissolved nitrate : phosphate atomic ratios of water entering coastal waters in many areas of the world. Human society may find that some desirable or dependent ecosystem interactions are compromised, rather than enhanced, as we alter these elemental ratios. Human-modulated changes in nutrient ratios that cause an apparent increase in harmful algal blooms may compromise the diatom-zooplankton-fish food web. It will be useful to improve our understanding of aquatic ecosystems and for management purposes if the assiduous attention on one element (e.g., $\mathrm{N}$ or P) was expanded to include the realities of these mutual interdependencies.
\end{abstract}

\section{Introduction}

This brief paper is about the ubiquitous influence of element ratios in aquatic food webs, an influence that transcends the metrics of individual element loading rates or concentrations. It begins with a discussion of the evolutionary origins of element stoichiometry that establishes their unmitigated influence on organic composition. Some of the early ideas about elemental ratios are reviewed to document their usefulness, even when only partially developed. Recently developed examples of how ecosystems and their parts behave from a stoichiometric perspective are then introduced, including a separate discussion of silicon (Si). It ends with some observations of how human-mediated changes in elemental flows have implications for understanding ecosystems. The major perspective of this paper is how the reciprocity of elemental flows in ecosystems produces inescapable constraints on aquatic ecosystems. Most of these generalities are not new (sensu Morowitz 1968), but they are worth occasionally restating them within a modern context, which is what I attempt here. The discussion is limited to carbon (C), nitrogen $(\mathrm{N})$, phosphorus $(\mathrm{P})$, and $\mathrm{Si}$, but could be fruitfully expanded with additional data and space.

\section{Life's Elemental Consequences}

There was no oxygen in the Earth's original atmosphere ca. four to five billion years ago. The atmosphere then was an anaerobic mixture of

* Tele: 225/578-6454; fax: 225/578-6326; e-mail: euturne( lsu.edu. mostly $\mathrm{NH}_{4}, \mathrm{CO}, \mathrm{CO}_{2}, \mathrm{H}_{2}, \mathrm{CH}_{4}, \mathrm{~N}_{2}$, and water vapor. Somehow, life on Earth began and evolved about a billion years later. Life forms creating and using gaseous divalent oxygen began their ascendancy about 2.3 billion ybp, but the toxic effects of oxygen for anaerobes were avoided as anaerobic metabolism became isolated within cells, a kind of metabolic refuge or strategic retreat. Gradually the Earth's thin surface layer became transformed, and not just in terms of its oxygen content, but also for many other elements.

The evolving organic matrix on the Farth's surface turned out to be quite different from the Earth's crust. About $99 \%$ of the Earth's crust consists of $46.4 \% \mathrm{O}, 28.2 \% \mathrm{Si}, 8.2 \% \mathrm{Al}, 5.6 \% \mathrm{Fe}, 4.2 \%$ $\mathrm{Ca}, 2.4 \% \mathrm{Na}, 2.9 \% \mathrm{Mg}$, and $2.1 \% \mathrm{~K}$. All of these eight are metals, except oxygen. In contrast, the organic matter in plants is mostly comprised of nine macronutrients: $44.5 \% \mathrm{C}, 42.5 \% \mathrm{O}, 6.5 \% \mathrm{H}$, $2.5 \% \mathrm{~N}, 0.3 \% \mathrm{~S}, 0.2 \% \mathrm{P}$, and three alkali or alkaline earth metals $(1.9 \% \mathrm{~K}, 1.0 \% \mathrm{Ca}$, and $0.2 \% \mathrm{Mg})$. Organic matter is thus the result of concentrating the relatively rare non-metals in the earth's crust. Plant nutritionists have identified additional elements known as micronutrients which are required for plant growth, but found in reduced quantities (Cl, Si, Mn, $\mathrm{Na}, \mathrm{Fe}, \mathrm{Zn}, \mathrm{B}, \mathrm{Cu}, \mathrm{Cr}, \mathrm{Mo}$, and $\mathrm{Co}$ ). Through an analysis of their functional role in plants and on an inter-elemental correlation analyses of their occurrence, Markert (1994) suggested that, in addition to the 11 elements mentioned, many other elements will be found to be essential for some organisms once measurement issues are resolved. Si (to be discussed later), for example, is 
essential for diatoms, but is not significant in most higher plants, and, $\mathrm{Ca}, \mathrm{B}$, and $\mathrm{Cl}$ are not considered essential in some bacteria and fungi (Markert 1998). The concentrations of these essential nutrients in plant biomass are highly correlated $\left(\mathrm{r}^{2}>\right.$ $0.8)$ with one another in the aggregate, as well as in different proportions within phylogenetic groupings (Markert 1994).

The concentration of elements and the evolution of elemental ratios in organic matter tells us quite a bit about the quantities and diversity of life forms. It tells us that life is working against a concentration gradient to extract or accumulate these elements, and that this metabolic work is not done element by element, but simultaneously in interrelated and, perhaps, subtle ways for many elements. The implication of this simple observation is that affecting the availability of one element will have consequences for individuals and populations. The result is that the evolution of life's biogeochemistry has yielded a reciprocal arrangement of abiotic and biotic parts whose status and functional abilities are co-dependent.

The examples discussed below are meant to illustrate how this reciprocity is reflected in the proportionality of elements moving into, accumulating within, and moving out of the biochemical packages (which are not inert machinery, as sometimes described, because they are capable of inventive adaptation) ranging from cells to ecosystems. I use examples from the aquatic sciences, because of the aquatic emphasis of this journal. The general issues, I think, should be applicable to all ecosystems (and at many scales) and are important in the management of ecosystems.

\section{Early Quantification of Elemental Stoichiometry in Aquatic Food Webs}

Results from early quantifications of ecosystem stoichiometry have had such profound influences on our understanding of aquatic systems that further work on the subject seems eminently worthwhile. Redfield (1973) had some keen insights about these biotic-abiotic relationships which began with measurements of nitrate and phosphate in the ocean. When Redfield looked at some results of chemical analyses to determine the concentration of phosphate, nitrate, and carbonate $\mathrm{G}$ above $1,000-\mathrm{m}$ depth in the western Atlantic Ocean, he observed that the concentration of $\mathrm{G}$, $\mathrm{N}$, and $\mathrm{P}$ not only changed with depth, but that these changes also varied proportionally. The ratio of the newly appearing $\mathrm{C}$, nitrate, and phosphate was the same in the organisms originally in the surface waters before they sank to deeper waters, undergoing decomposition along the way (Fig. 1). These ratios became known as Redfield ratios. Red-
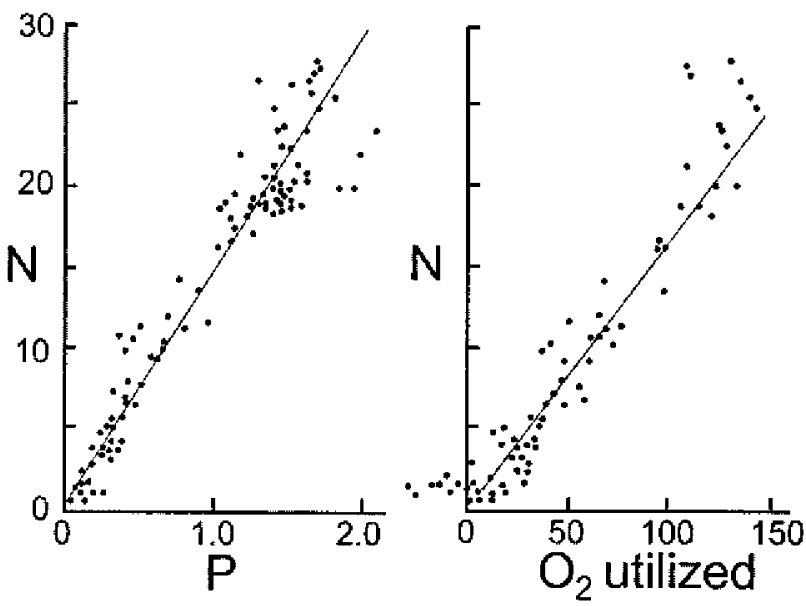

Fig. 1. The relationship between nitrate-N (y axis) and both phosphate-P (left panel) and oxygen used (right panel) for waters from above $1,000 \mathrm{~m}$ in the western Atlantic. Ocean. The concentrations are in $\mathrm{mg}$ atoms $\mathrm{m}^{-3}$. Adapted from Redfield et al. (1968).

field (1973, p. 14) said that his ideas about nutrient ratios:

"sprung entirely from my teaching of physiology. Where one could determine, by measuring the nitrogen in the urine, the oxygen and carbon dioxide exchange in the lung. ... the idea was what the body gave out was a product of what it was burning. And it was burning things in a perfectly definite proportion."

Redfield (1958 p. 14) noted the generality of these observations:

\begin{abstract}
"It is a recognized principle of ecology that the interaction of organisms and environment are reciprocal. The environment not only determines the conditions under which life exists, but the organisms influence the conditions prevailing in their environment" (Note that this paper has a ratio of 1:15:105::P:N:C. Richards [1958] added silicate to the list and slightly modified the ratios, which were determined to be $1: 16: 16$ : 270;:P:Si:N:O)."
\end{abstract}

Redfield (1988) distinguished between two different nutrient ratios based on the concentration of an element and the amount of that element released by the organism upon death. His idea was about the products of decomposition, which were determined by knowing the concentration of nutrients in the surface waters and in the water with the decomposing organisms. It was the change in the constituents that he monitored and drew his conclusions from, not the in situ concentration of the elements. The release of elements upon death is in nearly constant proportions, but may be dif- 
ficult to observe amidst the confounding influence of other factors, including a relatively low rate of change compared to initial concentrations. The in situ concentration was the result of a continuing dance conducted under the influence of various biotic and abiotic conductors. It was the elemental ratios of the changes in concentration that were similar to the cellular constituents.

Redfield (1978) thought it the most important idea that he'd ever had, and it appears to be his most famous idea. It has been broadly applied to other locations and ecosystems because it was documented well, presented persuasively at the right time and place, and has robust practical and theoretical usefulness. Support for the idea of growth limiting nutrients sprang from these relationships. Because an organism was composed of elements with certain proportions relative to one another, the uptake of these same elements might be affected by the balance between protoplasmic demand and external availability. If a nutrient concentration was sufficiently high to overcome substrate limitations (and not too high to inhibit-a rare circumstance), then one element and not another might limit growth if its supply (or loading) was low enough, for example, under the influence of varying light, temperature, turbulence, or a third element. A system or organism might be influenced by these changes as it moved vertically or horizontally, or remained in place. Species extirpation and exploitation might accompany these adjustments which occur everywhere in the microscopic to the macroscopic worlds. Species live in relationship to the elemental supply of not one element, but of a matrix of elements. This perspective can be much more realistic than an approach that includes only the flow of energy among various ecosystem parts. It still undervalues the complexity of ecosystems if only because the behavior of organisms is not included (e.g., Verity and Smetacek 1996; Dayton and Sala 2001). It also provides some insights that single-element perspectives do not.

\section{Element Stoichiometry in Cells and Ecosystems}

Three simple observations about food webs contribute to understanding food web stoichiometry: nutrient deficiency is commonly observed for primary producers and consumers, all predators require food, and prey are a heterogeneous mixture of nutrients. Although the following examples come from freshwater systems rather than marine systems, because they are a ready source for many parts of freshwater lakes, the discussion is intended to be appropriate for all aquatic ecosystems. This is not an unreasonable conclusion for many reasons, including the observation that both freshwa-

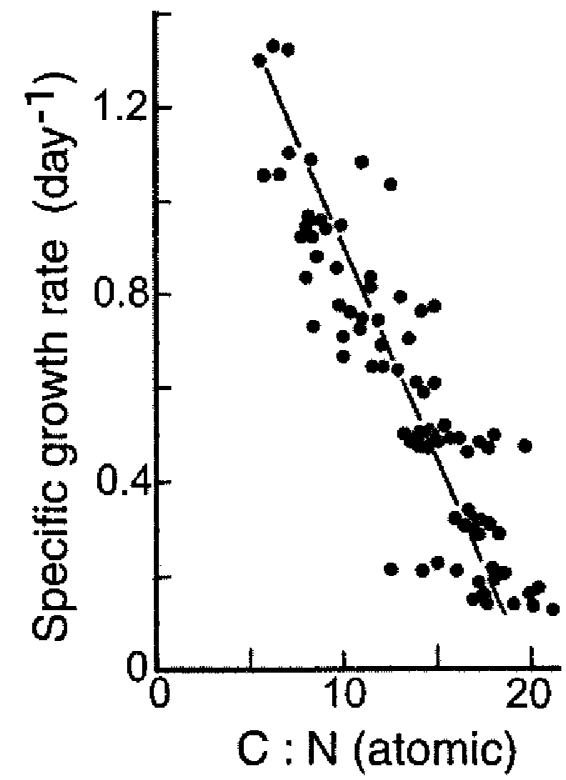

Fig. 2. The relationship between algal specific growth rate and the $\mathrm{C}: \mathrm{N}$ ratio in cultured algae (redrawn from Goldman $1980)$.

ter and marine systems behave similarly to changing $\mathrm{N}$ and $\mathrm{P}$ concentrations and ratios (e.g., Guildford and Hecky 2000).

\section{Cellular Level}

Cellular organelles (e.g., nucleus, ribosomes, membranes, mitochondrion, etc.) are not stoichiometrically equal, which implies that their balance must be considered in view of all processes of the entire cell. The variation in their $\mathrm{N}$ and $\mathrm{P}$ content may range from $9 \%$ to $15 \%$, and from $0.3 \%$ to $5 \%$, respectively, creating $\mathrm{N}: \mathrm{P}$ ratios ranging from $>$ 100:1 to 5:1 (Elser et al. 1996). The functions of organelles are therefore dependent on the supply and turnover of elements, and may not be able to perform their tasks as well if the rest of the cell does not have sufficient elemental resources and in the right combination. Rapid growth in prokaryotes, for example, requires ribosomal DNA (for cell division), which has a relatively higher $\mathrm{P}$ content and lower N:P ratio than eukaryotic ribosomes. Faster growing organisms contain more ribosomal RNA which is rich in P. Slower growth results in a lower percent $\mathrm{P}$ in the whole organism, and a higher N:P ratio. If $\mathrm{P}$ is in sufficient supply, then the C:N ratio may reflect the growth rate, e.g., in algae (Fig. 2). These elemental relationships might change during different growth stages.

\section{Predators and Prey}

Predators and prey have different nutritional requirements which affect element recycling rates, 


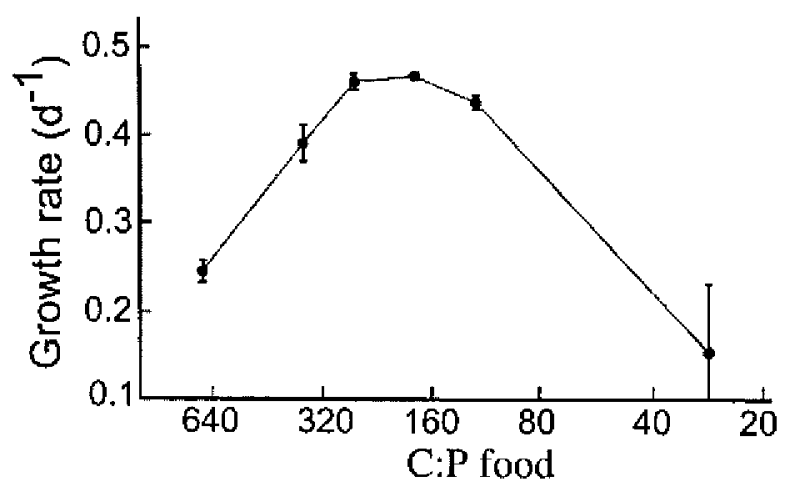

Fig. 3. The growth rates of Daphnia magna fed algae with different C:P ratios. Adapted from Plath and Boersma (2001).

element ratios, and organism growth efficiency. Because plants are relatively enriched in $\mathrm{C}$ compared to predators, the plant's energy can be used by consumers to accumulate nutrients. If nutrients are deficient, the ingested plant's energy may be dissipated by the consumer rather than within the larger food web; the consumer may even abandon one prey search pattern for another. The human equivalent might be a sandwich: the hungry among us will eventually search for at least a minimum level of quality and amount of food to be put between the two slices of bread, or we will search for alternative food. Plath and Boersma (2001) provide a freshwater example. They examined the nutritional quality of algae fed to Daphnia magna, a freshwater crustacean. They experimentally altered the $\mathrm{P}$ content of the algae and examined the response of Daphnia in terms of its growth parameters. The variations in the $\mathrm{C}: \mathrm{P}$ ratio of the algae affected Daphnia growth rates which were greatest at an intermediate level (Fig. 3). A lower nutritional quality of food was compensated for by a higher feeding activity (not shown), however. Plath and Boersma interpreted these results to demonstrate that the energy in the $C$ bonds was used to acquire the $\mathrm{P}$ in short supply. Plath and Boersma (2001, p. 1267) carried these observations further, noting that there will be consequences of this differential uptake efficiency for microbes: "As excess carbon most likely mainly dissipates as carbon dioxide, it will not be available to other trophic levels, and hence we could not expect a higher bacterial biomass in phosphorus-limited systems."

\section{Consumer Competition}

The variations in element recycling rates affect a species' elemental ratios and possibly the result of interspecific competition. Main et al. (1997) showed how differences in freshwater zooplankton $\mathrm{N}: \mathrm{P}$ ratios are related to their specific growth rates.
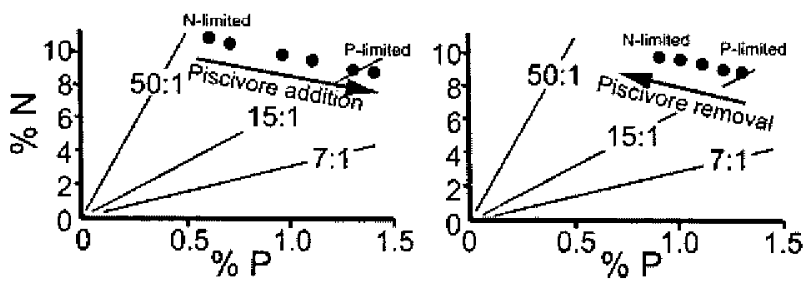

Fig. 4. Changes in the $\mathrm{P}$ and $\mathrm{N}$ content of the zooplankton community (dry weight) in two freshwater lakes following the addition or removal of a bass that feeds on minnows. The minnow's preferred food is Daphnia magna (low N:P) rather than the co-existing calanoid copepods (high N:P). The dotted lines are N:P ratios (atomic). Data (filled circles) are for weekly measurements of zooplankton. Shifts in the phytoplankton nutrient limitation during the experiments are indicated (from $\mathrm{N}$ to $\mathrm{P}$ or from $\mathrm{P}$ to N). Adapted from Elser et al. (1996).

Compared to calanoid copepods, Daphnia have a higher grazing rate, grow faster (higher P content), and have a lower $\mathrm{N}: \mathrm{P}$ ratio. While feeding on food with a low N:P, calanoid copepods will recycle ingested food (as a by-product) at an even lower N:P ratio than that in their food. In this way a. calanoid copepod will preferentially retain the relatively scarcer N. Daphnia, which have a lower $\mathrm{N}: \mathrm{P}$ ratio, recycle ingested food with a relatively higher $N: P$ ratio than is in their food, and recycle $\mathrm{P}$ with less efficiency. Calanoid copepods recycle the $\mathrm{N}$ in their food resources efficiently if $\mathrm{N}$ is scarce, resulting in the conservation of limiting nutrients (Sterner 1990). These differences in energy and nutritional costs can determine the outcomes of interspecific competition.

\section{Food Webs}

Elser et al. (1988) provide an example of how the behavior of predators can change the N:P ratios of food webs in lakes. They manipulated the zooplankton food web in two freshwater lakes by controlling zooplankton predators (i.e., minnows), and indirectly affected phytoplankton growth limitation because of the altered $\mathrm{N}: \mathrm{P}$ ratio in the recycled materials. They accomplished this result by adding or removing bass which fed on the minnows (minnows prefer Daphnia magna over the alternative food source, a calanoid copepod; Fig. 4). As described in the previous example, Daphnia grow faster than calanoid copepods, and have a relatively higher $\mathrm{P}$ content (higher rRNA requirement). The accumulation of P results in a lower N:P ratio for the zooplankton community. Compared to calanoid copepods, Daphnia is a relatively poor recycler of $\mathrm{P}$, and its presence or absence determines if the $\mathrm{N}: \mathrm{P}$ ratio available to phytoplankton is higher or lower, respectively. When bass are present, they graze on the minnows who prey on $D a p h-$ nia. The result is that when bass are added, then 


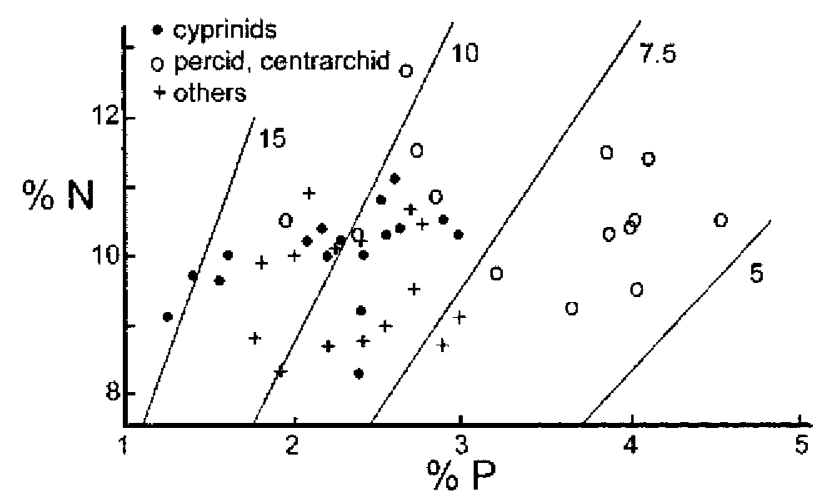

Fig. 5. Variations in the percent $\mathrm{N}$ and $\mathrm{P}$ in cyprinids, percids, centrarchids, and other freshwater fish. Adapted from Sterner and George (2000).

minnow grazing of Daphnia declines, the Daphnia population increases and stores $\mathrm{P}$, and phytoplankton growth limitation changes from $\mathrm{N}$ to $\mathrm{P}$ limitation. It was the presence or absence of Daphnia, controlled by predation, that changed the N:P ratio in the zooplankton community and thus affected the phytoplankton community composition.

Direct stoichiometric control by fish is also observed. The percent $\mathrm{N}$ and $\mathrm{P}$ in four different cyprinid fish species were examined by Sterner and George (2000) who were interested in the degree to which these ratios varied in relationship to the quality of their fishes food supply. Sterner and George concluded that the $\mathrm{C}: \mathrm{N}: \mathrm{P}$ ratios of the predators were more constrained than the food they ate, meaning that the predator had to actively control its diet. They provide the example of a fathead minnow (Pimphales promelas) which consumed food with a $\mathrm{C}: \mathrm{N}$ ratio ranging between 7 and 10.5 , but whose whole-body C:N ratio was a relatively constant 15 . The homeostatic control had to arise from differences in either $\mathrm{N}$ uptake or retention, or from lower gross growth efficiency. The N:P ratio in minnows and their food was similar, but varies among major fish species (Fig. 5), in part because of size, but also because of the proportional amount of bone structure. Assuming that their results apply generally, they concluded that the homeostatic modulation of nutrient flux by fish has an energetic cost arising from variations in food quality, which influences algal species composition. Other feedbacks can extend to beyond the feeding site if fish recycle nutrients back to their environment in different elemental ratios or even locations from the initial uptake site. Migratory fish, for example, provide significant amounts of $\mathrm{P}$ and $\mathrm{N}$ to freshwater and marine habitats (Krokhin 1975; Durbin et al. 1979; Helfield and Naiman 2001; Finney et al. 2002).

\section{Microbes}

We may focus attention on the large or charismatic organisms, but it is worthwhile to consider that the regulation of elemental ratios within aquatic food webs is strongly influenced by microbes, if only because they may dominate ecosystem biomass, the numbers of organisms, and the total ecosystem $\mathrm{C}$ flow (Pomeroy 2001). To paraphrase Karl (1999; cited by Pomeroy 2001): "Fish swim in a sea of microbes". Energetically, bacteria are directly dependent on the organics leaked from cells (e.g., dissolved organic matter leachates from phytoplankton) or lost when membranes are compromised (e.g., from the sloppy feeding of zooplankton or as a result of viral infection). Both fish and phytoplankton are also dependent on microbes because elemental recycling and re-absorption is dependent on, or passes through, microbes. A result of microbial death and growth is the return of nutrients to phytoplankton or the assimilation by microbial predators. Phytoplankton, microbes, and mesozooplankton (for example) seek their own elemental equilibrium with each doubling, and these doubling rates vary enormously. Compared to eukaryotes, the percent $\mathrm{P}$ of bacteria plasmalemma and ribosomes is three and two times higher, respectively (Elser et al. 1996) and the doubling rate of bacteria can be less than $1 \mathrm{~h}$ compared to 2 wk for zooplankton. The microbial community thereby indirectly affects food webs through a cascading series of influences that include regulation of element flows.

\section{The Stoichiometry of Silicate}

Understanding the role of $\mathrm{Si}$ in aquatic food webs is of special interest for several reasons, and notably so because of diatom-zooplankton-fish food webs.

$\mathrm{Si}$ is $28 \%$ of the Earth's crust, but the content in most plant material is less than $0.1 \%$, with a few important exceptions. Before the Paleozoic (ca. $570-225 \times 10^{6} \mathrm{ybp}$ ) there was no biological precipitation of silica (Siever 1992). The silica cycle before then was dominated by non-biological reactions among minerals, organic matter, and dissolved silica. Then, as now, the amount of silica loading to aquatic systems was controlled by tectonic activity, weathering, and hydrothermal seep activities. Sponges, radiolarians, and silica-secreting plants first appeared in the Paleozoic, long before diatoms arrived in the Cenozoic $65 \times 10^{6}$ ybp) and began to control the oceanic silica cycle.

Dissolved silicate is absorbed by diatoms to form the frustule, which is the external structure that can be quite beautiful and distinctive. Conley et al. (1989) assembled data on the silica content of di- 


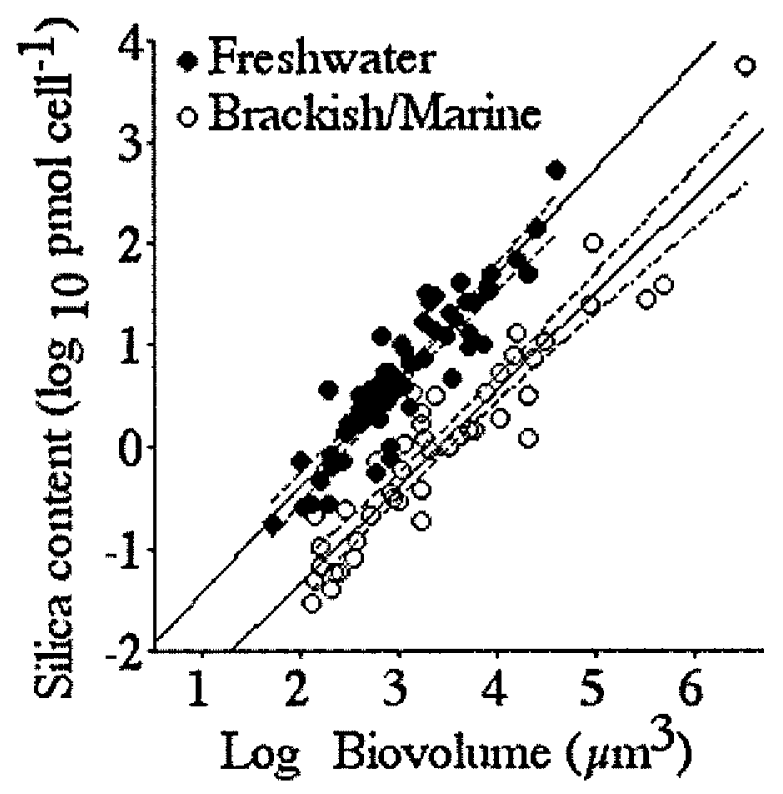

Fig. 6. The relationship between the silica content and cell volume for freshwater and brackish/marine diatoms. Linear regressions of the log-transformed data are shown. Adapted from Conley et al. (1989).

atoms and found that freshwater diatoms average one order of magnitude more silica per biovolume than marine diatoms (Fig. 6). Differences in the relative availability of silica in freshwater and marine systems might explain these disparities. Marine and freshwater diatom uptake of silica and growth depends on the silica content in the culture medium (Guilland et al. 1973; Paasche 1973; Tilman and Kilham 1976). Freshwater systems usually have a much higher concentration of silica than oceanic systems (typically $<2 \mu \mathrm{m}$ silicate in the open ocean), so evolutionary pressures favor lightly silicified marine diatoms. Conley et al. (1989) concluded that the half-saturation constants for the uptake of dissolved silica for marine species are an order of magnitude lower than those of many freshwater species. An additional consideration is that, unlike freshwater systems, re-entry into the upper mixed layer is difficult once marine diatoms sink out of the photic zone. The movement of the silica-bearing frustules and enclosed organic matter thus is a significant mechanism for element transfers within oceans.

Some evidence that the concentration of silicate is an important determinant of diatom abundance arises from field experiments by Egge and Aksnes (1992). These investigators studied the development of coastal phytoplankton communities in floating enclosures positioned near Bergen, Norway. They added various combinations of nutrients with and without silica to $11-\mathrm{m}^{3}, 4-\mathrm{m}$ deep plastic

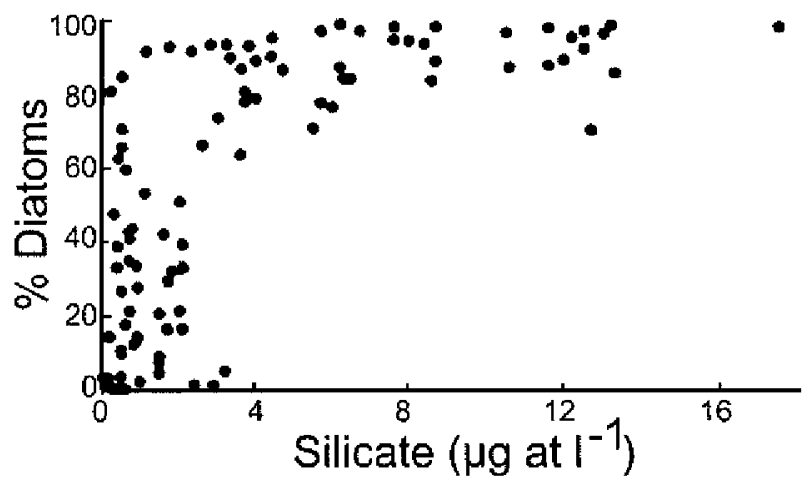

Fig. 7. The relationship between the percentage of the phytoplankton community that is diatoms and the concentration of silicate concentration in field experiments by Egge and Aksnes (1992).

bags and found that diatom dominance (usually Sheletonema costatum Grev. Cleve) occurred if the silicate concentration was above an approximate threshold of $2 \mu \mathrm{M}$, regardless of season (Fig. 7). Phaeocystis sp., a flagellate, appeared after a diatom bloom, but never when silicate concentrations were high. Diatom growth was $5 \%$ to $50 \%$ higher than flagellate growth when silica was not limiting. This growth rate is consistent with a literature review by Furnas (1990) who concluded that diatoms, under non-limiting conditions, have a much higher growth potential than non-diatoms, with a maximum in situ doubling rate of between 2 and 4 times daily, but that non-diatom growth rates are generally below 2.5 doublings per day. An important conclusion here is that diatom growth can be limited by the concentration of silicate, independent of the silicate: nitrate ratio.

The invention of diatoms had important consequences for the global cycling of other elements. Tréguer and Pondaven (2000) have argued that the increased supply of silica-containing dust to the oceans during the last glacial maximum (ca. 18,000 ybp) resulted in enough additional diatom production to explain how the atmospheric $\mathrm{CO}_{2}$ concentration dropped to $40 \%$ below present. This was a result, they argue, of the increased $\mathrm{C}$ sequestration in oceanic sediments through the favoring of the diatom growth over that of non-diatoms, and the subsequent lower recycling rate of plankton production back to the atmosphere.

Officer and Ryther (1980) proposed that $\mathrm{Si}$ is often the controlling nutrient determining whether an estuarine or marine phytoplankton community is composed of either diatoms or non-diatoms. The diatom based food web was described as contributing to desirable fishable populations and the non-diatoms to a flagellate ecosystem that often (but not always) was poor food for most grazers, 
TABLE 1. Some results of mesoscale field experiments or observations on how changing nutrient loading ratios affect coastal food webs.

\begin{tabular}{|c|c|c|c|}
\hline Source & $\begin{array}{l}\text { Area and } \\
\text { Conditions }\end{array}$ & Nutrients & Observations \\
\hline Smayda (1990) & review & $\mathrm{Si}: \mathrm{N}<1: 1$ & $\begin{array}{l}\text { based on strong inference, suggested that the } \\
\text { world-wide coincidental occurrence of } \mathrm{HAB} \\
\text { and changing Si:DIN ratios were related } \\
\text { (but not to a specific ratio) }\end{array}$ \\
\hline $\begin{array}{l}\text { Egge and Aksnes (1992); } \\
\text { Egge and Heimdal (1994); } \\
\text { Egge and Jacobsen (1997) }\end{array}$ & $\begin{array}{l}\text { Bergen, Norway } \\
11 \mathrm{~m}^{3}\end{array}$ & $\begin{array}{l}\text { + nitrate, +phosphate, } \\
\quad+\text { silicate }\end{array}$ & $\begin{array}{l}\text { diatom growth prevented by low Si concentra- } \\
\text { tion, increases with }+\mathrm{Si} \text {; increasing N:P re- } \\
\text { duces diatoms when Si sufficient, in favor of } \\
\text { flagellates }\end{array}$ \\
\hline Jacobsen et al. (1995) & $\begin{array}{l}\text { Norwegian fjord } \\
11 \mathrm{~m}^{3}\end{array}$ & +nitrate, +phosphate & $\begin{array}{l}\text { diatom increase until silicate deficiency, when } \\
\text { flagellates appeared; no increase in chl } a \\
\text { biomass or primary production; change in } \\
\text { species composition }\end{array}$ \\
\hline Turner et al. (1998) & Mississippi River delta & $\mathrm{Si}: \mathrm{N}<1: 1$ & $\begin{array}{l}\text { collapse of the diatom-zooplankton food web, } \\
\text { less fecal pellet production, at Si:N::1:1 pivot } \\
\text { point }\end{array}$ \\
\hline Kuuppo et al. (1998) & Baltic 150 liters & $\begin{array}{l}\text { +nitrate, +silicate, } \\
\text {-mesozooplankton }\end{array}$ & $\begin{array}{l}\text { diatom bloom developed with only small } \\
\text { amounts cascading into the heterotrophic } \\
\text { (microbial) food webs }\end{array}$ \\
\hline Chauvaud et al. (2000) & Bay of Brest & $\mathrm{Si}: \mathrm{N}<1: 1$ & $\begin{array}{l}\text { smaller spring bloom despite higher } \mathrm{N} \text { load- } \\
\text { ing; coincidental increase in suspension } \\
\text { feeding (exotic gastropod, Crepidula fomica- } \\
\text { ta) led to increased biodeposition; slow } \mathrm{Si} \\
\text { recycling sustains diatom population during } \\
\text { summer with less overall seasonality; avoid- } \\
\text { ance of undesirable blooms while the Si:DIN } \\
\text { ratio decreased (and N increased) }\end{array}$ \\
\hline Svensen et al. (2001) & $\begin{array}{l}\text { Bergen, Norway } \\
27 \mathrm{~m}^{3}\end{array}$ & $\begin{array}{l}\text { + nitrate, +phosphate, } \\
\quad+\text { silicate }\end{array}$ & $\begin{array}{l}\text { +Si triggered a diatom bloom; +NP (lower } \mathrm{Si} \text { : } \\
\mathrm{N} \text { ratios) had higher sedimentation rates }\end{array}$ \\
\hline Keller et al. (1990) & $\begin{array}{l}\text { Narragansett, Rhode Is- } \\
\text { land }\end{array}$ & $+\mathrm{N},+\mathrm{Si}$ & $\begin{array}{l}\text { fish growth low in control, intermediate with } \\
\quad+\mathrm{N} \text {; highest with }+\mathrm{N}+\mathrm{Si} \text { ( }+\mathrm{Si} \text { not done) }\end{array}$ \\
\hline
\end{tabular}

and the motile species were able to concentrate to undesirable concentrations, some of which were toxic or noxious. Richards (1958) used approaches similar to those of Redfield (1934) to determine that $\mathrm{Si}$ and $\mathrm{N}$ are incorporated into diatoms at a 1:1 atomic ratio, which reflects the $\mathrm{Si}: \mathrm{N}$ in their protoplasm. Officer and Ryther (1980) noted that dinoflagellates increase following silica depletion in many systems and noted the varying and important differences in the recycling rates of $\mathrm{Si}, \mathrm{P}$, and $\mathrm{N}$, but made no specific mention of Si:N ratios. Smayda (1990) did take notice of their importance, however. He reviewed the empirical coincidence of higher $\mathrm{N}$ and $\mathrm{P}$ nutrient loading, declining Si:N and Si:P ratios, and increasing world-wide incidence of often recurring blooms of non-siliceous phytoplanktonic groups, including harmful algal blooms (HAB). He developed the strong inference that nutrient ratios and the appearance of nuisance phytoplankton blooms were causally related. The results of many recent field experiments, in which nutrient loading rates have been experimentally-manipulated, support Officer and Ryther's (1980) and Smayda's (1990) conclusions (Table 1): the addition or reduction of silicate supplies results in a rise or fall in diatom abundance; the Redfield ratio of $\mathrm{Si:N}: 1: 1$ is a sensitive pivot point below which diatoms, their predators, and zooplankton fecal pellet production declines precipitously; and the flagellate food web is competitively enabled when the $\mathrm{Si}: \mathrm{N}$ is $<1: 1$, and may contain noxious or toxic phytoplankton. Changing either the supply of $\mathrm{Si}$ or the ratio of $\mathrm{Si} N \mathrm{~N}$ can, it seems, have quite dramatic effects on these aesthetically and economically important aquatic food webs, which also include avians and mammals.

\section{A World View of N:P and Si:N Ratios}

These stoichiometric relationships within natural systems occur within the context of probable future changes in nutrient loadings. The significance of human changes to $\mathrm{C}, \mathrm{N}$, and $\mathrm{P}$ cycling (e.g, fertilizers, mining, industrial production, and air pollutants) can be illustrated by expressing their commercial production as a percentage of the standing stocks of these elements in vegetation. Markert (1998) provided both numbers, and these data were updated in the case of $\mathrm{N}$ production to include $\mathrm{N}$ fixation by agricultural legumes and rice, and for $\mathrm{NO}_{\mathrm{x}}$ emissions (Kaiser 2001). A comparison was not made for dissolved silicate (DSi) because data are only available for $\mathrm{Si}$, which would 


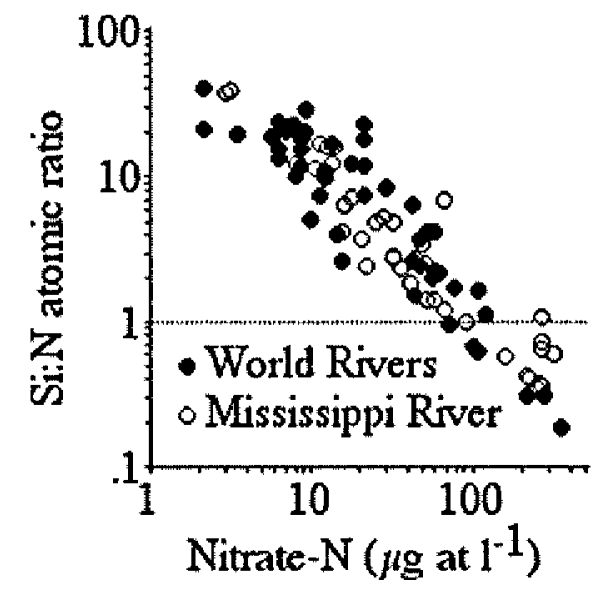

Fig. 8. The relationship between nitrate concentration ( $\mathrm{x}$ axis) and the dissolved Si:nitrate ratio in the main channel of large rivers of the world, 42 major sub-basins of the Mississippi River, and 82 small U.S. watersheds. The data are described in Turner et al. (in press).

not be soluble, in most cases, unlike most forms of $\mathrm{N}$ and $\mathrm{P}$. In order of increasing percentages they were: $\mathrm{P}<\mathrm{N}<\mathrm{C}(0.03 \%, 0.41 \%$, and $0.73 \%$, respectively). $\mathrm{N}$ loading has been increasing in many rivers of the world (Howarth et al. 1996; Vitousek et al. 1997; Gloern 2001), primarily as the mobile nitrate ion (Turner et al. in press). The global supply of new silicate is relatively stable because it is primarily determined by weathering and dissolution, and not by human activity. Tilman et al. (2001) estimated that $\mathrm{N}$ and $\mathrm{P}$ fertilizer use (gross weight) will continue to increase by 2.4 and 2.7 times, respectively, the application rate in 2000 . This increase is not equal for $\mathrm{N}$ and $\mathrm{P}$ when expressed on a molar basis. On a molar basis, the world's use of $\mathrm{N}$ fertilizer each year is 50 times that for $\mathrm{P}$ fertilizer. These numbers suggest that $\mathrm{P}$ is becoming relatively more limiting as the world's ecosystems move towards higher concentrations of $\mathrm{N}$ and $\mathrm{P}$. The DSinnitrate ratio should decline and the dissolved nitrate: $\mathrm{P}$ ratio should increase as $\mathrm{N}$ loading to aquatic systems continues to rise. These changes are already observed in many of the world's largest rivers (Fig. 8) and in coastal waters over the last 20 years (Rahm et al, 1996; Fisher et al. 1988; Justic et al. 1995a,b; del Almo et al. 1997; Allen et al. 1998; Correll et al. 2000; Humborg et al. 2000). As nitrate concentration increases, the ratio of dissolved $\mathrm{N}: \mathrm{P}$ increases above the Redfield ratio of $16: 1$ and below the DSinitrate ratio of 1 ; 1. With further similar changes, the disruption of the diatom-zooplankton-fish food web is likely to occur with greater frequency and over a larger area.

\section{Conclusions}

Descriptions of the biogeochemical evolution of life on Earth indicates that there must be a balance among the accumulation of many elements, and that there is not just one master element. Life evolved and is sustained by concentrating a few relatively rare elements in the Earth's crust into an organic matrix with semi-stable elemental ratios. These ratios may vary over the short term and long term within and among species, communities, and ecosystems, but there are long-term bounds to these ratios in life forms that determine the composition of ecosystems and the material flows within and among ecosystems. The examples discussed revealed several perspectives of just how sensitive plants, microbes, animals, and ecosystems are to variations in various elemental ratios. There is a growing set of empirical evidence demonstrating how nutrient availability and recycling and accumulation are intermingled with the activities of many life forms, and that the life forms are diverse because of these relationships. In other words, the response to nutrient additions and depletions is a community response and involves more than a single nutrient. The response affects many elemental ratios and therefore many species. These relationships have a bearing on how we manage our natural resources.

Some early attempts to manage aquatic ecosystems were based on the then-prevalent agricultural model of production. Experiments in Scotland were undertaken during World War II and thereafter to determine how fish production in semienclosed coastal basins responded to fertilizer applications (Nixon et al. 1986). The experiments were a success, more fish were produced. These were simple demonstrations of how nutrients influenced food webs that is now documented elsewhere. The model in these experiments was an agricultural model of more fertilizer $=$ more food. Agriculturists have not stopped doing their experiments, but they are now much more sophisticated-they recognize that today's society is much more complicated than when they started doing their experiments with single nutrient additions. Farm management now must be concerned about nutrient runoff, economics, hybridization, invasive species, pests, species losses, biocide contamination, ground water pollution, etc. Farmers know that there is an upper limit to the positive responses one nutrient has on crop yield and quality, and that there is sometimes a negative response. Aquatic ecosystem management is at least as complicated as farm crop management, if only because most marine crops are self-seeding, the economic product is a mixture of prey species, and the major har- 
vest (usually fish) moves through many mediums throughout their cycle of spawning, growth, and harvest.

Human alteration of some elemental fluxes and domination of others make this management that much more difficult. We must expect that there are consequences for how and what organisms adapt to these alterations, now evident in the subtle and sometimes not-so-subtle changes of organism assemblages. We may find that some desirable or dependent interactions are compromised, rather than enhanced, as the great geochemical engineers, humans, alter elemental cycling rates and locations. Some of these compromises are of immediate significance, e.g., eutrophication, the loss of charismatic species, development of noxious pests, and effects on market economies and human health. The result of these changes may even be the creation of alternative steady states with distinctively different food webs. Ecosystem models based on nutrient stoichiometry for freshwater lakes predict the existence of alternating high grazer and grazer-free states with eutrophication (Andersen 1997) and manipulations of fish biomass can influence the presence or absence of macroalgal abundance with consequential effects on habitat structure (Scheffer 1990). An assiduous attention to the management of one species or one element (e.g., $\mathrm{N}$ in coastal systems and $\mathrm{P}$ in freshwater) must give way to the realities of the interdependencies within the human realm and the ecosystem of which we are a part. We need not only more experimentation and observation, but also a coalescence of perspectives that brings together natural history, physics, en ergy flow analyses, and nutrient stoichiometry (and others) into an integrated and testable whole view of life (e.g., Verity and Smetacek 1996; Dayton and Sala 2001). Being predictable does not mean that changes are desirable, or that societal behavior will change. Knowing the patterns is part of intelligent participation in the process of artful management, and providing that knowledge is a proper role for scientists.

\section{ACKNOWLEDGMENTS}

This analysis was supported by grants from the National Oceanic and Atmospheric Administration, Coastal Occan Program. The editorial review of S. Nixon, N. N. Rabalais, and 3 anonymous reviewers greatly improved manuscript drafts. The interactions with, and writings by, Q. Dortch, J. Downing, J. J. Elser, D. Justic, L. R. Pomeroy, and N. N. Rabalais are gratefully acknowledged.

\section{Literature Gited}

ALIEN, J. R. D., J. SLINN, T. M. Stiammon, R. G. Hartnoli, AND

S. J. Hawkins. 1998. Evidence for eutrophication of the Irish
Sea over four decades. Limnology and Oceanograbhy 43:19701974.

Anderson, T. 1997. Pelagic Nutrient Cycles: Herbivores as Sources and Sinks. Springer-Verlag, New York.

Chauvaud, L., R. Jean, O. Ragueneau, and G. Thouteau. 2000. Long-term variation in the bay of Brest ecosystem: Benthicpelagic coupling revisited. Mamine Ecology Progress Series 200:3548 .

ClOERN, J. E. 2001. Our evolving conceptual model of the coastal eutrophication problem. Morine Ecology Progress Series 210: 223-353.

Conley, D. J., S. S. KIHAAM, AND E. ThERIOT. 1989. Differences in silica content between marine and freshwater diatoms. Limnology and Oceanography 34:205-213.

CoRrEIL, D. L., T. E. JoRDAN, AND D. E. WeILER. 2000. Dissolved silicate dynamics of the Rhode River watershed and estuary. Estuaries 23:188-196.

DAYTON, P. K. AND E. SALA. 2001. Natural history: The sense of wonder, creativity and progress in ecology. Scientia Marina 65: 199-206.

del Almo, Y., B. Quégumer, P. Tréguer, H. Breton, AND L. LAMPERT. 1997. Impacts of high-nitrate freshwater inputs on macrotidal ecosystems. II. Specific role of the silicic acid pump in the year-round dominance of diatoms in the Bay of Brest (France). Marine Ecology Progress Series 161:225-237.

Dirmin, A. G., S. W. Nixon, and C. A. Ontatt. 1979. Effects of the spawning of the alewife, Alosa pseudoharengus, on freshwater ecosystems. Ecology 60:8-17.

EGGE, J. K. AND D. L. AKSNEs. 1992. Silicate as regulating nutrient in phytoplankton competition. Marine Ecology Progress Series 83:281-289.

EGGE, J. K. AND A. JACOBSEN. 1997. Influence of silicate on particulate carbon production in phytoplankton. Marine Ecology Progress Series 147:219-230.

EGGE, J. K. AND B. R. HEIMTAL. 1994. Blooms of phytoplankton including Emiliania hrxxleyi (Haptophyta). Effects of nutrient supply in different N:P ratios. Sarsia 79:333-348.

ELSER, J. J., D. R. DOBberfuHL, N. A. MACKAY, AND J. H. SchamPEL. 1996. Organism size, life history, and N:P stoichiometry. Biascience 46:674-684.

Elser, J. J., M. M. Elser, N. A. MACKAY, AND S. R. CARPENTtr. 1988. Zooplankton-mediated transitions between $\mathrm{N}$ and $\mathrm{P}$ limited algal growth. Limnology and Oceanography 33:1-14.

Finney, B. P., I. Gregory-Eaves, M. S. V. Douglas, and J. P. SMOL. 2002. Fisheries productivity in the northeastern Pacific Ocean over the past 2,200 years. Nature 416:729-733.

FISHER, T. R., L. W. HARDIN, JR., D. W. STANLEY, AND L. G. WARD. 1988. Phytoplankton nutrients, and turbidity in the Chesapeake, Delaware, and Hudson estuaries. Estuarine Coastal and Shelf Science 27:61-93.

FURNAS, M. J. 1990. In situ growth rates of marine phytoplankton: Approaches to measurement, community and species growth rate. Joumal of Plankton Research 12:1117-1151.

GoLDMan, J. C. 1980. Physiological processes, nutrient availability and the concept of relative growth rate in marine phytoplankton ecology, p. 179-194. In P. Falkowski (ed.), Primary Production in the Sea. Plenum, New York.

GUILDFORD, S. J. AND R. E. HECKY. 2000. Total nitrogen, total phosphorus, and nutrient limitation in lakes and oceans: Is there a common relationship? Limnology and Oceanography 45: $1213-1223$.

GUILLARD, R. R. L., P. KIIJIAM, AND T. A. JACKSON. 1978. Kinetics of silicon-limited growth in the marine diatom Thalessiosira preudonara Hasle and Heimdal (=Cyclotella nana Hustedt). Journal of Phycology 9:238-237.

HELFIEID, J. M. AND R. J. NAIMAN. 2001. Effects of salmon-derived nitrogen on riparian forest growth and implications for stream productivity. Ecology 82:2408-2409.

HOWARTh, R., W. G. Bilden, D. SWANEy, A. TOWNSEND, N. Ja- 
WORSET, K. LAJTHA, J. A. DOWNTING, R. ELMGREN, N. CARACO, T. JoRDAN, F. BERENDSE, J. FrenEy, V. KuDEmarov, P. Murdoch, AND Z. ZHAO-LIANG. 1996. Regional nitrogen budgets and riverine $\mathrm{N}$ and $\mathrm{P}$ fluxes for the drainages to the North Atlantic Ocean: Natural and human influences. Biogeochemistry 35:75139

Humeorg, C., D. Conley, L. Rahim, F. Wulff, A. Cosiasu, and V. ITTEKKоT. 2000. Silicon retention in river basins: Far-reaching effects on biogeochemistry and aquatic food webs in coastal marine environments. Ambio 29:45-50.

JACOBSEN, A., J. K. EgGE, AND B. HemMDAL. 1995. Effects of increased concentration of nitrate and phosphate during a spring-bloom experiment in mesocosm. Joumal of Experimental and Marine Biology and Ecology 187:239-251.

Justic, D., N. N. Rabalais, AND R. E. Turner. 1995a. Stoichiometric nutrient balance and origin of coastal eutrophication. Marine Pollution Bulletin 30:41-66.

Justić, D., N. N. RabAlais, R. E. Turner, AND Q. DORTCH $1995 \mathrm{~b}$. Changes in mutrient structure of river-dominated coastal waters: Stoichiometric nutrient balance and its consequences. Estuarine and Coastal Shelf Science 40:339-356.

KAISER, J. 2001. The other global pollutant: Nitrogen proves tough to curb. Science 294:1268-1269.

KART, D. M. 1976. A sea of change: Biochemical variability in the north Pacific subtropical gyre. Ecosystems 2:181-214.

Kelifr, A. A., P. H. Dofring, S. P. KFtly, AND B. K. Suldivan. 1990. Growth of juvenile Atlantic menhaden, Brevortia tyrannas (Pisces: Clupeidae) in MERL mescocosms: Effects of eutrophication. Limnology and Oceanogrophy 35:109-122.

KROKHN, E. M. 1975. Transport of nutrients by salmon migrating from the sea into lakes, p. 158-156. In A. D. Hasler (ed.), Coupling of Land and Water Systems. Springer-Verlag, New York.

KuUPPo, P., R. Autio, H. KuOsA, O. SEÄL, AND D. S. TANSKANFN. 1998. Nitrogen, silicate and zooplankton control of the planktonic food-web in spring. Estuarine and Coastal Shelf Science 46 . $65-75$.

MAIN, T. M., D. R. DOBBERftHL, AND J. J. Elser. 1997. N:P stoichiometry and ontogeny of crustacean zooplankton: A test of the growth rate hypothesis. Limnology and Oceanography 42 : $1474-1478$.

MARKERT, B. F. 1998. Distribution and biogeochemistry of inorganic chemicals in the environment p. 165-222. In $G$. Schuurmann and B. Markert (ed.), Ecotoxicology. Wiley and Sons, Inc., New York

MARKERT, B. F. (ED.). 1994. The biological system of the elements (BSE) for terrestrial plants (Glycophytes). The Science of the Total Enviromment 155:211-228.

Morowtiz, H. J. 1968. Energy Flow in Biology. Academic Press, New York.

Nixon, S. W., G. A. Oviatt, J. Frtthsen, And B. Sullivan. 1986. Nutrients and the productivity of estuarine and coastal marine ecosystems. Journal of Limnological Saciein of South Africa 12:43-71.

OfFICER, C. B. AND J. H. Rrther. 1980. The possible importance of silicon in marine eutrophication. Marine Ecology Progress Series 3:83-91.

PAAscine, E. 1973. The influence of cell size on growth rate, silica content, and some other properties of four marine diatoms species. Norwegian Joumal of Botany 20:197-204.

Plath, K. AND M. BoERsma. 2001. Mineral limitation of zooplankton: Stoichiometric constraints and optimal foraging. Ecology 82:1260-1269

Pomeroy, L. R. 2001. Caught in the food web: Complexity made simple? Scientia Marina 65:31-40.
RAHM, L., D. CONLEY, P. SANDÉN, F. WULFF, AND P. STÁLNACKE. 1996. Time series analysis of nutrient inputs to the Baltic Sea and changing DSi/ $\mathrm{N}$ ratios. Marine Ecology Progress Series 130 : 221-228.

REDFIELD, A. C. 1934 . On the Proportions of Organic Derivatives in Sea Water and Their Relation to the Composition of Plankton, James Johnstone Memorial Volume. The University of Liverpool Press, Liverpool, U.K.

REDFIELD, A. C. 1958. The biological control of chemical factors in the environment. American Scientist 46:205-222.

ReDFIELD, A. C. circa 1978. Alfred C. Redfield, Naturalist 1890 1983: His scientific career, from interviews by E. R. Marsh. Copy from Data Library and Archives, Woods Hole Oceano graphic Institution, Woods Hole, Massachusetts.

REDFIELD, A. C., B. H. Ketchum, AND F. A. RicilarDs. 1968. The influence of organisms on the composition of seawater, p. 2677. In M. N. Hill (ed.), The Sea, Volume 2. Interscience Publishers, John Wiley, New York.

RicharDs, F. A. 1958. Dissolved silicate and related properties of some western North Atlantic and Caribbean waters. Jow mal of Manine Research 17:449-465.

SCHFFFER, M. 1990. Multiplicity of stable states in freshwater systems. Hydrobiologia 200/201:475-486.

Siever, R. 1992. The silica cycle in the Precambrian. Geochima et Cosmochimica Acto 56:3265-3272.

SMAWA, T. J. 1990. Novel and nuisance phytoplankton blooms in the sea: Evidence for a global epidemic, p. 29-40. In E. Granéli, B. Sundstrom, L. Edler, and D. M. Anderson (eds.), Toxic Marine Phytoplankton. Elsevier Science Publishers, New York.

STERNER, R. W. 1990. The ratio of nitrogen to phosphorus resupplied by herbivores: Zooplankton and the algal competitive arena. American Naturalist 136:209-229.

SternFr, R. W. AND N. B. George. 2000. Garbon, nitrogen, and phosphorus stoichiometry of cyprinid fishes. Ecology 81:127140 .

Svensen, C., I. K. Egge, ANd J. E. Stuansen. 2001. Can silicate and turbulence regulate the vertical flux of biogenic matter? A mesocosm study. Marine Ecology Progress Series 217:67-80.

Tilman, D., J. FArgione, J. B. WolfF, C. D'Antonio, A. DoBson, R. Howarth, D. Schindler, W. H. Schlesinger, D. SLMberLOFF, AND D. SWACKHAMER. 2001. Forecasting agriculturally driven global environmental change. Science 292:281-284.

TIMMAN, D. AND S. S. KILHAM. 1976. Phosphate and silicate growth and uptake kinetics of the diatoms Asterionella formosa and Cyclotella meneghiniana in batch and semicontinous culture. foumal of Phycology 12:375-383.

TrEgutr, P. AND P. PONDAVEN. 2000. Silica control of carbon dioxide. Nature 406:357-359.

Turner, R. E., N. Qureshi, N. N. Rabalais, Q. Dortch, D. JUSTIC, R. SHAw, AND J. COPE. 1998. Fluctuating silicate:nitrate ratios and coastal plankton food webs. Procedings of the $\mathrm{Na}$ tional Academy of Sciences 95:13048-13051.

Turner, R. E., N. N. RABALAIs, D. JUstTC, AND Q. DorTCH. 2002. Global patterns of dissolved N, P and Si in large rivers. Bio geochemistry.

VeRITy, P. G. AND V. SmETAGeK. 1996. Organism life cycles, predation, and the structure of marine pelagic ecosystems. $M a$ rine Ecology Progress Series 130:277-293.

VITOUsek, P. M., J. D. Aber, R. W. HowArTh, G. E. LIKENs, P. A. Matson, D. W. Schindler, W. H. Schlesinger, AND D. G. TILMAN. 1997. Human alteration of the global nitrogen cycle: Sources and consequences. Ecological Applications 7:737-750.

Received for consideration, January 23, 2002 Accepted for publication, May 1, 2002 